inOedia $\quad \begin{aligned} & \text { InMedia } \\ & \text { The French Journal of Media Studies }\end{aligned}$

8.1. $\mid 2020$

Ubiquitous Visuality

\title{
The Body in Motion - AIDOC Study Day
}

September 10, 2020, Maison de la Recherche Germaine Tillion, University of Angers

\section{Myriam Mellouli}

\section{(2) OpenEdition \\ 12 Journals}

\section{Electronic version}

URL: http://journals.openedition.org/inmedia/2142

DOI: 10.4000/inmedia.2142

ISSN: 2259-4728

\section{Publisher}

Center for Research on the English-Speaking World (CREW)

\section{Electronic reference}

Myriam Mellouli, "The Body in Motion - AIDOC Study Day", InMedia [Online], 8.1. | 2020, Online since 15 July 2020, connection on 01 February 2021. URL: http://journals.openedition.org/inmedia/2142 ; DOI: https://doi.org/10.4000/inmedia.2142

This text was automatically generated on 1 February 2021

(c) InMedia 


\section{The Body in Motion - AIDOC Study Day}

September 10, 2020, Maison de la Recherche Germaine Tillion, University of Angers

\section{Myriam Mellouli}

1 The symposium entitled "The Body in Motion" took place on September $10^{\text {th }}$, 2020 at Maison de la Recherche Germaine Tillion (MRGT) in the University of Angers (France). It was organized by an interdisciplinary organization mainly composed of Ph.D. candidates and young researchers called the AIDOC ${ }^{1}$ and chaired by Louise Coueffé at the time of the scholarly event. The latter was supported by various research units (3L.AM, ESO, TEMOS) and federative research structures (IRPaLL, SFR Confluences). As the name of the organization suggests, the symposium highlighted an interdisciplinary approach of the body in motion: six presentations in history, film and media studies, literature and philosophy were held throughout the three sessions of the day.

2 It is striking how the body as an object of study is conducive to interdisciplinarity. The previous research conferences organized by the AIDOC, "Parcours de gamins" (Kids' Journeys²) 2018, and "La nature dans tous ses états" (Nature in all its forms) 2019, already expressed this interdisciplinary approach. In hindsight, this symposium invited the participants to broaden significantly their academic horizons. More than the body in motion, strictly speaking, it also explored the challenges related to human embodiment. That is to say the way human beings live and own - or do not own - their body in the world since, as Engelhardt puts it, "embodiment in this world does not stop at the edges of one's body, but is extended into other objects marked by one's will." 3 Indeed, the body is not only a material container of our alleged soul, it is also a symbolic vessel filled with one's desires, fantasies and social allegiances. Its complex sensitive and symbolic nature makes it "a barometer of social relationships and longterm historical processes" for the sociologist Norbert Elias. ${ }^{4}$ Considering this complexity, the body has progressively become a full-fledged object of study since the 1980 's in various academic fields, especially in social science. ${ }^{5}$ If the sociologist Norbert Elias does not separate the body from the social structure the study of the body in 
motion per se and subsequently of the human embodiment has found a renewed academic interest in more recent research, from Bourdieusian ${ }^{6}$ papers dwelling on the concept of habitus ${ }^{7}$ to conference and symposium topics ${ }^{8}$.

"Le corps en mouvement" brought together Ph.D. candidates from different French universities. Dominique Sagot-Duvauroux, the chairman of the federative research structure Confluences, delivered the opening remarks and noted the topicality of the body in motion as an object of study in the context of the COVID-19 pandemic. Bodies moving from place to place have to be disciplined and their movement has to be controlled. Body strength is tested and sometimes defeated by the coronavirus contamination and the subsequent illness. The constrained body fails. These introductory remarks on the current events were closely related to the three sessions of the symposium: "Corps disciplinés", "Corps à l'épreuve", "Corps contraints" ("Disciplined bodies", "Tested bodies", “Constrained bodies").

4 The first session, "Corps disciplinés", focused on the organization of the body movement and its institutionalization in public and private social spheres. The body is prompted to direct its movement in a normative frame. The first presentation evoked the high value given to the military uniform in the French Army. Remi Mazauric (Université Paris 1 Panthéon-Sorbonne) built on his personal experience in this public institution to analyze its impact on the physical and psychological training of individuals. The Army uniform constitutes at the same time a symbol of affiliation to the respected institution and the crowning of a personal achievement. If types of weapons and beret color can constitute a collective attribute to distinguish a large part of the Army, some clothing items like the military Medal and decorations can distinguish a soldier or a smaller group of soldiers. The uniform signals the possible actions on field operations and the possibilities of motion in them. If the current French Army is a professional one where the soldiers discipline their body with their consent, it was not the case of the Spanish children in the middle of the $20^{\text {th }}$ century. Aliénor Asselot de Maredsous (Université Paris 3 Sorbonne Nouvelle) shed light on the willingness of a society, imbued with Romantic imagery, to bridle the children's body. For that purpose, she screened striking drawings of well-behaved children who stand straight and "bent" children (niño travieso) taken from children's books of the era. They illustrate the articulation between the individual body of the child and the social body in the taming process: children have to show their good behavior through their body and ill-behaved children are identified by physical characteristics (posture, dirt on the skin and clothes). Their body bears the stigma of their assumed perversion.

The second session, "Corps à l'épreuve", offered two disciplinary outlooks on the sportsperson's body in motion. In sports, the body is tested in its capacity to move: the sporting gesture can be automatic like a machine's, or more unstable, vulnerable. The first presentation highlighted the theoretical issues of the Cartesian Machine-Body. Adrienne Estrada (Université de Nantes) invited us to think about the athlete's body in endurance sports through Cartesian philosophy. For Descartes, the unity between body and mind constitutes an epistemological obstacle. The philosopher thus states that the immaterial mind commands the body: it is only a material extension of the mind. Taking into account the Cartesian mind-body dualism, she compared the athlete's body to the automaton since the low-intensity movement of the body in endurance sports is automatic like the movement of the cogs in a machine, yet threatened by wearisome effort and exhaustion. The following presentation studied one of the main sequences of 
the boxing film, the training sequence. ${ }^{9}$ It is generally characterized by the recording of various and continuous, uninterrupted movements of the boxer's body. Through filmic case studies mixing sociological and psychanalytic approaches, Myriam Mellouli (Le Mans Université) analyzed the dynamics of interruption during the screened repetitive boxing training. When the training moves are disturbed, the high-intensity pace of the training montage breaks brutally. For example, desire embodied in a temptress or a tempter works as a disruptive force against the boxer's body in motion and holds back the celerity of the motion picture. Desire interrupts the global sporting gesture and isolates body parts; the balance of power and the feeling of physical omnipotence of the boxer are thus tested. Solitary boxing moves dwindle on the screen, strengthening programs and shadow-boxing are put at risk by physical attraction, by the strength of desire.

6 The third and last session, "Corps contraints", spotlighted bodies that move in a marginal way and marginal bodies that move. The movement of these bodies is constrained: migrants see their physical integrity threatened in their illegal passage and limits of the range of the movement are met in some neurodegenerative diseases. The first presentation studied the autobiographical narratives of people with Parkinson's disease. Cathy Dissler (Université d'Angers) insisted on the personal experience of the authors. Self-expression of the patients is put forward in the writings: she explained via thorough literary analyses how the evolutionary neurodegenerative disease is experienced by patients with Parkinson's disease. The body goes through phases of transition where the person realizes that the body can no longer perform a gesture that it was used to doing before the long-term illness. If it is marked by a sense of loss of body abilities, the process of writing gives a meaning to what she calls "mouvements entravés" ("impeded moves"). Between the writings and in the text itself, a variety of unheard voices are allowed to raise and to dialog with each other, creating polyphony and a sense of communality of experiences. Shared experiences are also at the core of the digital narratives of bodies in exile studied in the last presentation of the day. Through the works of contemporary artists and a montage movie based on amateur footage, Ann Valérie Epoudry (ENSA Toulouse) gave a talk in media studies and foregrounded unseen experiences. Bodies of migrants cannot be seen by outside sources since their location is officially nowhere and kept secret: their body seems to not exist for anyone except themselves. It is not located even if digital technology, thanks to the Internet, gives a sense of ubiquity to the art viewer. Without digital technology, it is not possible to see the experience of the exiled body without being an exile. She analyzed how digital technology, especially smartphones, reinvented in moving images the exile narrative of the bodies. Real bodies are constrained by the non-identification of space and water, which is at same time limitless and a sort of large jail cell for the migrants who can drown at any time. If they were to die at sea, only digital bodies would remain.

7 The symposium ended with concluding remarks by the members of the organization: they noted with satisfaction the diversity of disciplines and approaches offered by the six presentations of the day. It was followed by a panel discussion on the career possibilities offered by a Ph.D. degree. This symposium held in the context of a pandemic - hygiene guidelines were strictly followed - was possible thanks to the members of an organization who, with their caring attention and the overall nurturing 
atmosphere of the day, allowed the Ph.D. candidates to make an interesting contribution to body studies.

\section{NOTES}

1. Association Interdisciplinaire des Doctorants de l'Ouest - Confluences in English Interdisciplinary Association of Western Doctoral Students - Confluences

2. All translations by author unless indicated otherwise

3. Hugo Tristram Engelhardt, THE FOUNDATIONS OF BIOETHICS (1986). In Thomas H. Murray, "On the Human Body as Property: The Meaning of Embodiment, Markets, and the Meaning of Strangers", University of Michigan Law Journal, 20 (4, Summer 1987), 1067. Available at: https:// repository.law.umich.edu/mjlr/vol20/iss4/7. Accessed November 132020

4. Mike Atkinson, "Norbert Elias and the Body", in Routledge Handbook of Body Studies (Abingdon: Routledge, 2012),49., Routledge Handbooks Online. Available at: https:// www.routledgehandbooks.com/doi/10.4324/9780203842096.ch3. Accessed November 132020

5. Chris Shilling, "The Rise of Body Studies and the Embodiment of Society: A Review of the Field", Horizons in Humanities and Social Sciences 2 ( 1, 2016), 1-14, https://core.ac.uk/download/ pdf/46663852.pdf Accessed November 132020

6. Bourdieu, P. Distinction: A Social Critique of the Judgement of Taste. (Cambridge, MA, Harvard University Press 1984).

7. Louise Holt, "Embodied social capital and geographic perspectives: performing the habitus". Progress in human geography, vol. 32 (2, 2008), 227-246. Hasan Sankır, "Construction of Gender Roles in 17th-Century Ottoman Dancing Boys (Köçeks). Habitus, Body and Dance ", Asian Journal of Social Science, 48(1-2,2020), 44-68. Loïc Wacquant, "L'habitus comme objet et méthode d'investigation. Retour sur la fabrique du boxeur. ", Actes de la Recherche en sciences sociales, 4 ( $\left.{ }^{\circ} 184,2010\right)$, Le Seuil, 108-121.

8. "Écoute et figurabilité des corps en mouvement" (Listening and figurability of bodies in motion) INALCO 2019; "Paradigmes des corps en mouvement" (Paradigms of bodies in motion) Université Claude Bernard Lyon 1, 2018

9. It is important to note that the author of this presentation is also the author of this review.

\section{AUTHOR}

\section{MYRIAM MELLOULI}

Since 2017, Myriam Mellouli specializes in research on artistic expressions and representations of boxing. She obtained a Master's Degree in Literature (ENS Lyon) thanks to a Master's thesis in Comparative Literature on the aesthetics of survival in boxing literature and started film studies with a Master's thesis on spaces in boxing films. Since 2019, she has pursued her specialization on 
"the Noble Art" by preparing a Ph.D. dissertation in film studies entitled "Le film de boxe: le combat d'un genre" (Le Mans Université, Laboratoire 3L.AM).

myriam.mellouli@univ-lemans.fr 